\title{
Analysis Of The Economic Effects Of Low Income Housing Tax Credits
}

David M. Mitchell, Ph.D., Missouri State University, USA

Russell McKenzie, Ph.D., Southeastern Louisiana University, USA

\begin{abstract}
The development of low income housing projects can provide both social and economic benefits to a state. As an economic engine, low income housing projects provide construction jobs and positively impacts long term employment. This paper examines the specific impact investments in low income housing projects and associated tax credits.
\end{abstract}

Keywords: Low income housing, tax credits, economic impact

\section{INTRODUCTION}

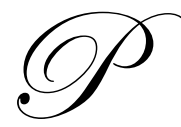

roviding affordable housing to disadvantaged or low income households is a laudable goal, and is actively pursued by many segments of government and society. However, the task raises several key questions: How can we best achieve this goal? Where should this housing be located? Who should provide it? These are questions that should be answered to ensure the most efficient allocation of public or private funds. One popular method of providing affordable housing to these groups is to encourage private investments through the use of tax credits. This is exactly what the Low Income Housing Tax Credit (LIHTC) program was designed to do.

The LIHTC program was instituted in the Tax Reform Act of 1986 as a method to subsidize the development of low income housing using federal tax credits. This federal program grants developers income tax credits over a ten year period for developing housing that meets certain requirements for low income households. The maximum rent that can be charged for a LIHTC qualified unit is determined by the family size and the area's median adjusted gross income which may differ from county to county.

These federal credits are allocated to states proportionally based on population. As of 2007, each state receives the greater of $\$ 1.95$ in federal tax credits per capita or $\$ 2.275$ million in credits. In addition, to the federal program, many states have a state subsidy that will match up to $100 \%$ of the federal program. That is, in addition to federal credits, developers may also take advantage of state tax credits. A major purpose of this paper is to determine the marginal impacts of this state-level program (in addition to the federal assistance), and to determine the impacts of the program in general.

In addition, the question of where to locate these housing units is examined. The costs and benefits associated with building housing units in urban areas and rural areas are likely to differ due to differences in economic characteristics of those areas. Where will such efforts have the biggest impacts?

Evidence of the short run and long run impacts a state level LIHTC program has on the state economy in terms of employment, gross state product, and the change in the state's tax revenue position are investigated. The study area includes all metropolitan and non-metropolitan counties in Missouri. The purpose is to provide statelevel administrators with some insight regarding the effectiveness of alternative policies in a representative U.S. state. 


\section{RESEARCH METHODOLOGY}

A random weighted sample of representative projects built between 2000 and 2005 in Missouri was selected, which included housing projects designed to meet elderly and non-elderly clients. Projects that were in the Metropolitan Statistical Areas (MSA) of Kansas City and St. Louis were examined separately. Projects that occurred in Missouri's other more 'minor' MSAs (such as Columbia, Springfield, Joplin, Jefferson City, and St. Joseph) were grouped together in a field called 'Other Metro'. Finally, all remaining projects were classified as 'Rural'. Thirty projects were studied in the sample with seven from the Kansas City MSA, nine from the St. Louis MSA, five from 'Other Metro', and nine from 'rural'.

Data on the hard and soft costs in construction and operations in the audited financial statements were acquired on all 30 projects and were analyzed using IMPLAN to determine the economic effect that each individual project had generated ${ }^{1}$. All cost data was adjusted for inflation to reflect expenditures and impacts in 2004 dollars. Economic impacts from construction were ascertained first. Then estimates on the ongoing yearly economic impact from operations were determined and extrapolated out over 20 years using an inflation rate of $2.5 \%$ and a discount rate of $4.632 \%$ (the prevailing rate on 10 -year U.S. bonds).

Determining the inframarginal effect of the LIHTC program versus the total effect is not purely an academic exercise. Malpezzi and Vandell (2002) and Case (1991) examined whether the LIHTC program lead to an increase in the production of low income housing or if developers simply substituted subsidized housing for unsubsidized housing. They found no evidence that the LIHTC increased the available supply of housing, but rather that developers simply took the tax credit for housing that they would have produced anyway. These results were upheld by Sinai and Waldfogel (2005) who found that the rate of substitution was between 50\% and 66\% meaning that for every 3 housing projects built with the tax credits, 1.5 to 2 of them would have been built anyway. If these estimates are accurate, then the state and federal governments are subsidizing a desired activity that would occur anyway and the respective governments would be better off putting their revenues to better uses. Once again, this is an important issue to answer not only on efficiency grounds, but on equity grounds as well. If indeed developers are taking tax credits to build housing that would otherwise have been built, then average taxpayers, who are relatively poorer, are subsidizing developers, who are relatively richer.

To aid in determining how many of the projects are built from the state LIHTC program alone, a simple comparison of the low income housing built per capita between Missouri and Kansas was conducted. Our analysis shows that the Missouri LIHTC program increased the production of low income housing by $43 \%$ over a state that relies on the federal program only". The first part of our results section will focus on the 'total' effect, from both the federal and state programs, of producing and operating low-income housing. This will provide us with an upper bounds estimate of the economic effects. Later results will present the economic effects from just the state LIHTC program.

\section{RESULTS}

As this analysis examines monetary flows over time, it is important to distinguish between the short-run impacts and those considered long-run. In addition, since all flows do not occur during the same period, it is useful to present the effects in terms of the net present value of future flows. Each of these perspectives is presented below.

\section{Short Run Effects}

The first five tables below present the short-run effects of the production of low income housing under the tax subsidies. Table 1 lists the total number of low income housing units developed, while Table 2 shows the

\footnotetext{
${ }^{1}$ IMPLAN is a software package that is used in Input-Output analysis to determine the size and nature of economic shocks using a classification system of 509 different sub-sectors of the economy.

${ }^{2}$ Further research is under way to refine this estimate. The reader should keep in mind that future research might increase or decrease this value.
} 
economic impact on a per housing unit developed basis for each of the four areas. Included in this table is the average cost (in 2004 dollars) to build each unit of low income housing, the percentage of that cost that is on average covered by both the federal and state LIHTC, and the average taxes and fees collected from construction. It is, by far, more expensive to develop low income housing in the Kansas City and St. Louis MSA that it is in the smaller metro or rural areas. This is partly a reflection of the higher costs of living, in terms of land acquisition costs, legal fees, input prices, etc. in Kansas City and St. Louis relative to the rest of the state. In addition to this, Dunn, Quigely, and Rosenthal (2005) show that enforcing prevailing wages in the construction of low income housing raises the costs of development. Since wages tend be higher in the larger metro areas than in the smaller metro and rural areas, development costs would also be higher.

Table 1. Total Low Income Housing Built by Year and Region

\begin{tabular}{lccccc}
\hline & Kansas City & St. Louis & Other Metro & Rural & Total \\
\cline { 2 - 6 } $\mathbf{2 0 0 0}$ & 615 & 541 & 198 & 539 & 1,893 \\
$\mathbf{2 0 0 1}$ & 1,532 & 1,329 & 414 & 684 & 3,959 \\
$\mathbf{2 0 0 2}$ & 1,310 & 1,506 & 418 & 334 & 3,568 \\
$\mathbf{2 0 0 3}$ & 759 & 1,300 & 387 & 951 & 3,397 \\
$\mathbf{2 0 0 4}$ & 1,204 & 1,431 & 191 & 487 & 3,313 \\
$\mathbf{2 0 0 5}$ & 1,611 & 2,748 & 695 & 442 & 5,496 \\
\hline
\end{tabular}

Following this, the valued added to the state economy (per unit built) is divided into the three categories of direct, indirect, and induced effects. Value added is identical to gross state product (GSP), which is the state equivalent of a nation's gross domestic product (GDP), and looks only at the increase in value that accrues to the inputs in the production process. This is followed by the amount of taxes and fees that federal, state, and local governments can expect to reap from each unit of low income housing constructed.

Table 2. Short Run Economic Impacts of Low Income Housing (2004 Dollars Per Unit of Low Income Housing)

\begin{tabular}{lccccc}
\hline & Kansas City & St. Louis & Other Metro & Rural & Average \\
\cline { 2 - 6 } Construction Cost / Unit & $\$ 128,195$ & $\$ 115,911$ & $\$ 67,405$ & $\$ 59,475$ & $\$ 95,563$ \\
LIHTC / Costs & $5.2 \%$ & $9.3 \%$ & $17.9 \%$ & $17.9 \%$ & $10.5 \%$ \\
Value Added Direct & 65,932 & 73,462 & 37,791 & 30,851 & 52,009 \\
Value Added Indirect & 21,764 & 16,397 & 9,537 & 6,196 & 13,473 \\
Value Added Induced & 36,278 & 37,797 & 18,701 & 10,428 & 25,801 \\
Taxes & 8,935 & 8,431 & 4,584 & 3,054 & 6,251 \\
Fees & 2,203 & 506 & 505 & 421 & 908 \\
\hline
\end{tabular}

We can now extrapolate the per unit housing impacts to all of the housing projects built in Missouri during 2000 to 2005 . Recall, that these economic effects are short term in that they are felt in the economy only as long as housing projects are being built. Table 3 presents the number of jobs that were created in each region within each year in terms of full time equivalency (FTE). In terms of FTE, the average number of jobs produced per year is 7,236. As expected, most of the jobs are being generated from construction in Kansas City and St. Louis.

Table 3. Employment Generated Statewide by Year and Region (FTE)

\begin{tabular}{|c|c|c|c|c|c|}
\hline & Kansas City & St. Louis & Other Metro & Rural & Total \\
\hline 2000 & 872 & 1,145 & 287 & 657 & 2,963 \\
\hline 2001 & 3,225 & 2,780 & 502 & 1,165 & 7,674 \\
\hline 2002 & 2,861 & 1,646 & 606 & 857 & 5,971 \\
\hline 2003 & 1,399 & 1,905 & 1,053 & 443 & 4,801 \\
\hline 2004 & 3,635 & 3,047 & 277 & 448 & 7,408 \\
\hline 2005 & 4,078 & 10,041 & 291 & 187 & 14,599 \\
\hline
\end{tabular}


Table 4 delineates the economic effects of constructing low income housing projects throughout the state in the four regions. As the interested reader can see, most of the output produced is from the primary MSAs. Gross State Product grew $\$ 156$ million in 2000 and almost $\$ 860$ million dollars in 2005. If low income housing had not been constructed in these years, output and gross state product could have theoretically been reduced by this amount. We state theoretically because it is not known what the developers would have done had they not built low income housing in the time frame under question.

Table 4. Total Value Added Statewide by Year by Region (2004 US\$)

\begin{tabular}{lccccc}
\hline & Kansas City & St. Louis & Other Metro & Rural & Total \\
\cline { 2 - 6 } $\mathbf{2 0 0 0}$ & $\$ 49,480,092$ & $\$ 68,718,173$ & $\$ 13,073,753$ & $\$ 25,588,453$ & $\$ 156,860,471$ \\
$\mathbf{2 0 0 1}$ & $175,666,387$ & $169,654,586$ & $24,324,954$ & $41,657,196$ & $411,303,123$ \\
$\mathbf{2 0 0 2}$ & $162,405,031$ & $103,677,571$ & $27,600,146$ & $34,931,000$ & $328,613,748$ \\
$\mathbf{2 0 0 3}$ & $81,491,296$ & $119,715,094$ & $46,269,833$ & $17,316,924$ & $264,793,147$ \\
$\mathbf{2 0 0 4}$ & $207,284,290$ & $187,179,119$ & $12,611,550$ & $16,973,865$ & $424,048,823$ \\
$\mathbf{2 0 0 5}$ & $233,944,038$ & $603,251,655$ & $13,740,810$ & $8,318,628$ & $859,255,130$ \\
\hline
\end{tabular}

Table 5 shows the value added and employment multipliers of constructing low income housing within each of the 4 regions. A dollar increase in initial production in Kansas City will have an ultimate effect of approximately $\$ 1.88$ on the state economy. The same dollar increase in initial production in a rural area will only increase GSP by $\$ 1.57$. In other words, there is a greater amount of 'leakage' of the indirect and induced effects in the smaller areas than in the two principal cities. If residents of Kansas City see their income increase because of an increase in demand for the products that they produce, they have more 'options' for spending those dollars 'locally' than does the same resident in a rural area. Since there are fewer businesses in a small town, more of the indirect and induced dollars will 'leak' out of the region/state to other regions/states. Table 5 illustrates the employment 'multiplier' that occurs from each initial job created in constructing low income housing. For employment, we can see that for every full time equivalent worker hired in construction, total employment would increase of 1.58 jobs. The state average is an increase of 0.50 jobs for every person initially hired in construction.

Table 5. Short Run Value Added and Employment Multiplier

\begin{tabular}{lccccc}
\hline & Kansas City & St. Louis & Other Metro & Rural & Average \\
\cline { 2 - 6 } Value Added & 1.88 & 1.75 & 1.73 & 1.57 & 1.64 \\
Employment & & & & & \\
Total & 1.70 & 1.66 & 1.60 & 1.47 & 1.58 \\
FTE & 1.58 & 1.52 & 1.52 & 1.42 & 1.50 \\
\hline
\end{tabular}

\section{Long Term Impacts}

The analysis to determine the long term impacts of operating and maintaining low income housing projects was similar to that used for the short term impacts. The economic impact from operations of each unit was estimated and was extrapolated to a hypothetical 100 unit housing project to make the estimates more meaningful to the reader. Table 6 highlights the relevant data. We can see that for every 100 units, there will be a approximately 5 to 10 full time equivalent jobs created depending upon where the low income housing units are located with the average throughout the state being 6.5 full time equivalent jobs. Similarly, the amount of value added created depends upon location, with projects operating in St. Louis generating almost two and a half times more output than in the smaller metro areas. The same can be said for tax revenue generation. The operations and maintenance of the project produces economic activity in the form of increased employment and spending, which is taxed and creates revenue for the state. Operating the hypothetical 100 housing unit in St. Louis will generate approximately $\$ 51,000$ in additional taxes every year, while in Jefferson City the same complex would generate slightly more than $\$ 20,000$ in additional taxes. 
Table 6. Total Employment and Value Added Generated (100 Unit Housing Project)

\begin{tabular}{lccccc}
\hline & Kansas City & St. Louis & Other Metro & Rural & Average \\
\cline { 2 - 6 } Employ FTE & 4.96 & 9.89 & 5.20 & 5.82 & 6.47 \\
Value Added & & & & & \\
Taxes & $\$ 337,604$ & $\$ 641,958$ & $\$ 262,537$ & $\$ 270,910$ & $\$ 378,252$ \\
\hline
\end{tabular}

Tables 7 and 8 are an extrapolation of the operations data per 100 housing units to the entire set of housing units operating in 2005 and are reported in 2004 dollars to follow convention with the previously reported data. These numbers are in yearly estimates. For example, operation and maintenance of the low income housing projects produced in Kansas City from 2000 to 2005 will result in 387 jobs in the state of Missouri (349 full time equivalency) per year. Statewide, the operation of the low income housing projects produced during the time frame in question will generate 1,720 jobs or about 1,544 full time equivalent jobs per year. Comparable scrutiny in terms of value added reveals that the operations of the projects increases GSP by almost \$96 million per year and increases tax revenue to the state of $\$ 7.5$ million per year.

Table 7. Total Employment, Value Added, and Taxes per Year (O and M)

\begin{tabular}{lcccc}
\hline & Employment & FTE & Value Added & Taxes \\
\cline { 2 - 5 } Kansas City & 378 & 349 & $\$ 23,736,969$ & $\$ 1,791,871$ \\
St. Louis & 995 & 876 & $56,845,381$ & $4,590,984$ \\
Other Metro & 129 & 120 & $6,046,225$ & 465,221 \\
Rural & 218 & 200 & $9,311,162$ & 703,488 \\
Total & 1,720 & 1,544 & $95,939,739$ & $7,551,565$ \\
\hline
\end{tabular}

Table 8. Long Run Value Added and Employment Multiplier By Location (O and M)

\begin{tabular}{lccccc}
\hline & Kansas City & St. Louis & Other Metro & Rural & Average \\
\cline { 2 - 6 } Value Added & 1.79 & 1.89 & 1.70 & 1.47 & 1.71 \\
Employment & & & & & 1.53 \\
$\quad$ Total & 1.86 & 1.83 & 1.65 & 1.40 & 1.72 \\
FTE & 1.69 & 1.61 & 1.53 & 1.56 \\
\hline
\end{tabular}

\section{Present Value and Final Results Summation}

As stated earlier, the economic impacts of constructing housing units between 2000 and 2005 were converted into 2004 dollars and the future flows of net benefits from operations was converted to real dollars (i.e. inflation adjusted) at an estimated annual rate of $2.5 \%$. In this last section, the present value of real net benefits of the LIHTC program, in terms of increased future value added, increased tax revenue from induced economic activity, and the 'cost' of the tax credit in terms of decreased tax revenue per year for the ten year lifespan of the credit, is calculated over a 20 years time span so that the reader can better understand the true impact of the program on the Missouri economy.

Table 9 includes the total effect from the LIHTC program in Missouri while Table 10 shows the multiplier in value added per dollar of state LIHTC. Recall that the total effect looks at the low income housing that has been built between 2000 and 2005; therefore, it does not include housing built before that time. Also recall, that there is a federal tax credit effect and a state tax credit effect that are both included here. Table 9 shows that the building and operation of the housing projects that were completed between 2000 and 2005 will grow the economy by $\$ 3.8$ billion. Most of that increase, $\$ 2.3$ billion, will happen in the short term and comes about due to the construction of the housing project while the remaining $\$ 1.5$ billion will be spread out over 20 years and comes about from the operations and maintenance of the projects. The state can expect to collect about $\$ 181$ million in additional taxes from the construction phase of the housing projects but to lose $\$ 624$ million in net taxes over the next 20 years of operations. Even though the state will see increased collections from additional economic activity generated from 
operating the projects, these taxes increases are not enough to cover the value of the lost tax revenue from issuing the tax credit to the developer

Table 9. Present Value of Benefits and Taxes from Construction and Operations (2004 US dollars)

\begin{tabular}{cccccc}
\hline & Kansas City & St. Louis & Other Metro & Rural & Total \\
\cline { 2 - 6 } Value Added & & & & & \\
Construction & $\$ 871,654,163$ & $\$ 1,130,393,880$ & $\$ 152,064,787$ & $\$ 163,168,138$ & $\$ 2,317,280,968$ \\
Operations & $375,759,618$ & $899,870,506$ & $95,712,612$ & $147,397,024$ & $1,518,739,760$ \\
$\quad$ Sub-Total & $1,247,413,781$ & $2,030,264,386$ & $247,777,399$ & $310,565,162$ & $3,836,020,728$ \\
Increased Taxes & & & & & \\
$\quad$ Construction & $78,310,856$ & $79,137,578$ & $11,719,944$ & $11,943,369$ & $181,111,747$ \\
Operations & $(165,262,747)$ & $(244,905,793)$ & $(99,873,146)$ & $(114,292,213)$ & $(624,333,900)$ \\
$\quad$ Sub-Total & $(86,951,891)$ & $(165,768,215)$ & $(88,153,202)$ & $(102,348,845)$ & $(443,222,153)$ \\
\hline
\end{tabular}

This last point is important and deserves further explanation. Recall that in order to build a low income housing project, workers must be hired, supplies ordered, bulldozers rented, lumber purchased, etc. All of these economic activities generate further economic activity through the forward and backward linkages. These activities are taxed by the state as income taxes, property taxes, sales and excise taxes, and other assorted fees and taxes. Furthermore, operating the low income housing project, once it is built, produces jobs and spurs economic activity which results in tax revenue for the state in a similar fashion as before. However, the state 'gives up' some tax revenue in the form of tax credits given to the developer.

Table 10 demonstrates the impact that each dollar of state low income housing tax credit has on the economy. Not surprisingly, the largest effect on gross state product happens in the major MSAs, while there is a smaller 'bang for the buck' in the smaller metro areas and the rural areas. This would suggest that if the state is simply interested in using its state low income housing tax credits as 'efficiently' as possible, it should support the building of low income housing in major metropolitan areas where it would see GSP increase by approximately $\$ 6.40$ for every dollar of tax credit, and oppose building in smaller metro areas and rural areas. The state also loses less money in tax revenues when the tax credits are given to projects in large cities. For every dollar in state tax credit given to develop projects in Kansas City, the state gains 55 cents in taxes for a net loss of only 45 cents. However, for a project developed in a rural county, the state can expect to only get back about 18 cents for a net loss of 82 cents per dollar of tax credit.

Table 10. Multipliers of the State LIHTC on the Present Value of Output and Taxes

\begin{tabular}{cccccc}
\hline & Kansas City & St. Louis & Other Metro & Rural & Total \\
\cline { 2 - 6 } Value Added & & & & & \\
Construction & 4.50 & 3.56 & 1.42 & 1.30 & 3.19 \\
Operations & 1.94 & 2.83 & 0.89 & 1.18 & 2.09 \\
Sub-Total & 6.44 & 6.39 & 2.31 & 2.48 & 5.28 \\
Increased Taxes & & & & & \\
Construction & 0.40 & 0.25 & 0.11 & $(0.10$ & 0.25 \\
Operations & $(0.85)$ & $(0.77)$ & $(0.93)$ & $(0.81)$ & $(0.86)$ \\
Sub-Total & $(0.45)$ & $(0.52)$ & $(0.82)$ & & $(0.61)$ \\
\hline
\end{tabular}

We now estimate the value, in real net present value dollars, of the impact of the state LIHTC program by separating out the federal effect from the state effect. The reader will note that we have not employed the estimates of Malpezzi and Vandell (2002), Case (1991), and Sinai and Waldfogel (2005) that the federal program simply subsidizes housing that would have been built anyway. In short, all of the total effect has been divided between the federal effect and the state effect so that if both the federal and state tax credit were removed, it is assumed that the production of low income housing would fall to zero. If indeed the estimates of Sinai and Waldfogel (2005) are correct, and $50 \%$ to $66 \%$ of the housing would have been built anyway, than these following numbers are an overestimation of the true economic impact. 
Table 11 lists the economic impacts on the state from the state level program only. In short, the reader can think of this in the following way: 1) A federal LIHTC exists but there is not a state level LIHTC program. 2) The federal program will generate the production and subsequent operation of some level of low income housing in the state. 3) A state LIHTC program is brought into existence that further spurs the production and operation of some additional low income housing. The increased economic activity that would we now observe is listed in Table 11. The reader will note that gross state product has increased by $\$ 1.6$ billion. Most of this increase, $85 \%$ is coming from the large metropolitan areas. Under this scenario, the state is losing even more money in taxes than previously. The explanation for this is quite straight forward. If there were only a federal LIHTC program, and not a state program, the state would have a positive flow of tax revenue in the short run and long run. This is because the federal program would spur some, but not as much, construction and subsequent operations which would generate tax revenue for the state from the increased economic activity. However, in this case, since the state does not have to pay out any state tax credits, all tax revenue is a net positive. However, once the state LIHTC program is put into place, the state now has to give up revenue in the form of the credit. At the same time the state LIHTC program generates some new project construction, but not as much as the federal program. In short, the inframarginal low income housing built from the state program is smaller than the inframarginal low income housing built from the federal program. Therefore, the state gets even less 'bang for the buck' than it does if all effects are spuriously lumped together.

Table 11. Present Value of Benefits and Taxes from Construction and Operations of the State Program Only

\begin{tabular}{cccccc}
\hline & Kansas City & St. Louis & Other Metro & Rural & Total \\
\cline { 2 - 6 } Value Added & & & & & \\
$\quad$ Construction & $\$ 378,297,907$ & $\$ 490,590,944$ & $\$ 65,996,118$ & $\$ 70,814,972$ & $\$ 1,005,699,940$ \\
Operations & $163,079,674$ & $390,543,799$ & $41,539,274$ & $63,970,309$ & $659,133,056$ \\
$\quad$ Sub-Total & $541,377,581$ & $881,134,743$ & $107,535,391$ & $134,785,280$ & $1,664,832,996$ \\
Increased Taxes & & & & & \\
$\quad$ Construction & $33,986,912$ & $34,345,709$ & $5,086,456$ & $5,183,422$ & $78,602,498$ \\
Operations & $(181,317,667)$ & $(286,040,374)$ & $(104,041,462)$ & $(120,595,369)$ & $(691,994,871)$ \\
$\quad$ Sub-Total & $(147,330,756)$ & $(251,694,665)$ & $(98,955,006)$ & $(115,411,947)$ & $(613,392,373)$ \\
\hline
\end{tabular}

This can be seen in Table 12 which illustrates the multiplier effects from the state LIHTC program when it is considered independently of the federal program. For every dollar of state LIHTC given to develop low income housing in Kansas City, the state sees GSP increase by $\$ 2.80$ - far less than it had when we lumped all effects together. Furthermore, when we consider the change in tax revenues for the state when building low income housing in rural counties, we can see that for every dollar of credit given out, the state will get back about 8 cents from additional economic activity. This is a net loss of 92 cents on each tax credit dollar.

Table 12. Multipliers of the State LIHTC on the Present Value of Output and Taxes (State Program Only)

\begin{tabular}{cccccc}
\hline & Kansas City & St. Louis & Other Metro & Rural & Average \\
\cline { 2 - 6 } Value Added & & & & & \\
Construction & 1.95 & 1.54 & 0.62 & 0.56 & 1.38 \\
Operations & 0.84 & 1.23 & 0.39 & 0.51 & 0.91 \\
$\quad$ Sub-Total & 2.80 & 2.77 & 1.00 & 1.07 & 2.29 \\
Increased Taxes & & & & & \\
Construction & 0.18 & 0.11 & 0.05 & 0.04 & 0.11 \\
Operations & $(0.94)$ & $(0.90)$ & $(0.97)$ & $(0.96)$ & $(0.95)$ \\
Sub-Total & $(0.76)$ & $(0.79)$ & $(0.92)$ & $(0.92)$ & $(0.84)$ \\
\hline
\end{tabular}

\section{CONCLUSIONS}

This paper has determined the total and inframarginal economic impacts in terms of output, employment and tax collection from the construction and operation of low income housing in Missouri. Furthermore, it has been determined that low income housing projects which originate in the primary MSAs of Missouri, i.e. Kansas City and St. Louis, will have a larger economic impact then projects in the rural and smaller metro areas. Even though the 
short run and long run employment multipliers are similar throughout the state, the value added of these jobs in the primary MSAs is higher generating output multipliers that are approximately equal to 6.4 versus approximately 2.4 in the rural and smaller MSA. This means that a 1 dollar increase in spending in the primary cities will generate $\$ 6.40$ in gross state product but the same dollar increase in other areas will only increase gross state product by $\$ 2.40$.

In the short run, the construction of housing in the LIHTC program has provided from between 3,000 to 14,600 jobs per year, increased gross state product by $\$ 2.4$ billion, and increased tax revenue by $\$ 191$ million. The long term operation of the low income housing put into use will generate an additional 1,544 jobs per year and raised gross state product by $\$ 3.8$ billion dollars over 20 years. Unfortunately, it does not appear that the tax credit 'pays for itself'. The state of Missouri can expect to collect about 39 cents back on average for every dollar in tax credit it distributes. However, when the state LIHTC program is examined in light of its effect separate from the federal effect we see that gross state product increases by only $\$ 1.6$ billion dollars over 20 years and that only 670 jobs will be generated. In addition, the state stands to reclaim only 16 cents of every dollar in tax credits it distributes.

So in short, several policy concerns can be addressed based on the findings of this study:

In general, tax credits are somewhat effective at generating increased economic activity. The short-run impacts include significant job creation and revenue collection.

In the long-run, revenue is lost due to the tax credits issued.

The long-run losses far exceed the short-run gains.

In the long-run value-added is significant, indicating increased economic activity.

States get far less return on state tax credits than on federal tax credits.

Metropolitan projects yield far better returns than do rural projects.

Given current issues in finance and real estate markets and trends in state budgets, state officials would be wise to exercise even more caution than normal in allocating state monies to alternative public projects. While tax credits may seem a viable means of promoting affordable housing, it may be more beneficial to utilize federal aid, while saving state funds for other projects. On the other hand, these credits are effective at generating economic activity and creating jobs. One must be aware of the difference between generating economic activity and generating tax revenues.

\section{AUTHOR INFORMATION}

David M. Mitchell is the Director of the Bureau of Economic Research and an Assistant Professor of Economics at Missouri State University. Dr. Mitchell's research interests and prior publications cover topics such as housing, urban/regional economic growth, and economic issues pertaining to water quality. He received his Ph.D. in economics from Oklahoma State University in 2001.

Russell McKenzie is an Assistant Professor of Economics at Southeastern Louisiana University in Hammond, Louisiana. Teaching interests include environmental economics, urban and regional economics, and economics of social issues. His research and publication topics include housing and urban/regional economics incorporating GIS into traditional economic analysis, and water resource economics. Professor McKenzie received his Ph.D. in Economics from Oklahoma State University in 2003.

\section{BIBLIOGRAPHY}

1. Case, Karl. "Investors, Developers, and Supply-Side Subsidies: How Much is Enough?”, Housing Policy Debate, 2(2), 341-356, 1991.

2. Cook, John, David M. Mitchell, and Bernard McCarthy. "Cost/Benefit Analysis of the Missouri LowIncome Housing Tax Credit Program", Missouri Housing Development Commission, Department of Economic Development of the State of Missouri, 2007. 
3. Cummings, Jean, and Denise DiPasquale. "The Low-Income Housing Tax Credit: An Analysis of the First Ten Years", Housing Policy Debate, 10(2), 251-307, 1999.

4. Davis, Craig. Regional Economic Impact Analysis and Project Evaluation, University of British Columbia Press, Vancouver, 1990.

5. Dunn, Sarah, John Quigley, and Larry Rosenthal. "The Effects of Prevailing Wage Requirements on the Cost of Low-Income Housing", Industrial and Labor Relations Review, 59(1), 141-157, 2005.

6. Lee, Chang-Moo, Dennis Culhane, and Susan Wachter. "The Differential impacts of Federally Assisted Housing Programs on Nearby Property Values: A Philadelphia Case Study”, Housing Policy Debate, 10(1), 75-93, 1999.

7. Malpezzi, Stephen and Kerry Vandell. "Does the Low-Income Housing Tax Credit Increase the Supply of Housing?", Journal of Housing Economics, 11(4), 360-380, 2002.

8. McClure, Kirk. "The Low-Income Housing Tax Credit as an Aid to Housing Finance: How Well Has It Worked?", Housing Policy Debate, 11(1), 91-114, 2000.

9. Minnesota IMPLAN Group, Inc., IMPLAN System (data and software), 1725 Tower Drive West, Suite 140, Stillwater, MN 55082

10. Saegert, Susan, Gary Winkel, and Charles Swartz. "Social Capital and Crime in New York City's LowIncome Housing”, Housing Policy Debate, 13(1), 189-226, 2002.

11. Sinai, Todd and Joel Waldfogel. "Do Low-Income Housing Subsidies Increase the Occupied Housing Stock?” Journal of Public Economics, 89(11-12), 2137-2164, 2005. 
Journal of Business \& Economics Research-August, 2009

Volume 7, Number 8

\section{NOTES}

